\title{
On the Mechanism for Radiosensitization of Microorganisms by Sodium Chloride with Special Reference to Their DNA Repair Capacity
}

\author{
Kazui Igarashi, Takeyuki Hasumi and Akira Matsuyama \\ The Institute of Physical and Chemical Research, \\ Wako-shi, Saitama-ken 351, Japan \\ Received November 30, 1977
}

\begin{abstract}
Some biological aspects of radiosensitization of microorganisms by $\mathrm{NaCl}$ at comparatively higher concentrations were studied. Among different strains of bacteria and yeasts, the radioresistant vegetative form was particularly sensitive to $\mathrm{NaCl}$ present during irradiations. With $E$. coli, such radiosensitizing effect of $\mathrm{NaCl}$ was abolished by mutations at the pol and rec loci or by the addition of certain solutes at the time of irradiation. The effective extracellular chloride concentrations for $E$. coli $\mathrm{B} / \mathrm{r}$ were not less than $0.1 \mathrm{M}$. When actinomycin D and chloramphenicol were added during reincubation of $E$. coli $\mathbf{B} / \mathrm{r}$ following irradiation in the presence of $\mathrm{NaCl}$, the radiation lethal effect was enhanced, the extent of which was almost independent of doses of irradiation. From these results together with the previous data, the basic mechanism for $\mathrm{NaCl}$ radiosensitization was discussed with special references to a possible role of $\mathrm{Cl}_{2}^{-}$radical anions as attacking species and to the inhibition of pol- and rec-dependent DNA repair systems as the primary cellular damage.
\end{abstract}

It has been reported that the presence of $\mathrm{NaCl}$ at comparatively high concentrations during irradiation results in the enhancement of the radiation lethal effect on certain bacterial and yeast cells. ${ }^{1,2}$ ) Concerning the radiation chemical basis of this $\mathrm{NaCl}$ radiosensitization, it was suggested that short-lived intermediates radiation-produced from $\mathrm{Cl}^{-}$ions such as $\mathrm{Cl}$ atoms and/or $\mathrm{Cl}_{2}^{-}$radical anions might be the attacking species. ${ }^{2 \sim 3)}$

Other halide ions were also found to sensitize bacterial cells when irradiated in their presence, although there seemed to be some difference in mode of action as compared with $\mathrm{Cl}^{-}$ions. ${ }^{2)}$ Similarly, bacterial spores and bacteriophages suspended in water or buffer were found to be sensitized to radiations by the presence of $\mathrm{Br}^{-}$ions during irradiation, and $\mathrm{Br}_{2}^{-}$radical anions formed by the reaction of $\mathrm{OH}$ with $\mathrm{Br}^{-}$were implicated as damaging species. ${ }^{6 \sim 7)}$ Closely relating to these radiation chemical studies, biological and biochemical approaches have been made in this laboratory to draw out the whole picture of the mechanism for the radiosensitization in the presence of $\mathrm{Cl}^{-}$ions during irradiation. One of trials along these lines is to search after the experi- mental conditions which reduce or remove the radiosensitizing effect of $\mathrm{NaCl}$ added during irradiation.

In the present paper, data on the removal of $\mathrm{NaCl}$ radiosensitization by mutations in DNArepair controlling genes and by the addtion of certain solutes at the time of irradiation will be described together with some other biological determinations at the cellular level. The mechanism for this sensitization will also be discussed.

\section{MATERIALS AND METHODS}

Strains and culture conditions. Strains and media used in an experiment to examine the radiosensitizing effect of $\mathrm{NaCl}$ on different microorganisms were as follows: $E$. coli strains $\mathrm{B}, \mathrm{B} / \mathrm{r}, \mathrm{B}_{\mathrm{s}-1}$ and $\mathrm{B}_{\mathrm{s}-\mathrm{z}}(\mathrm{B} 2$ broth containing $1 \%$ Kyokuto beef extract, $1 \%$ Daigo Polypepton and $0.5 \% \mathrm{NaCl}$ at pH 7.0), E. coli WP2 (try $\left.y^{-}\right)$ (Haas and Doudney minimal medium supplemented with $10 \mathrm{mg} /$ liter L-tryptophan), ${ }^{8\rangle}$ Pseudomonas fluorescens $\mathrm{B} 3-1$ (BBL trypticase-soy broth), Microccocus radiodurans $\mathrm{R}_{1}$ ( $\mathrm{B}$ broth containing $1 \%$ beef extract, $1 \%$ Polypepton, $0.5 \%$ yeast extract and $0.2 \%$ glucose

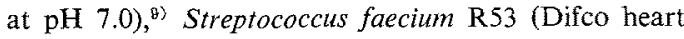
infusion broth), ${ }^{10)} M$. radiophilus $\mathrm{RBD}$ and Micrococcus sp. B12 (TGY medium), ${ }^{11,12)}$ Tetracoccus soyae F-8 $(1 \%$ Polypepton, $1 \%$ beef extract and $2 \% \mathrm{NaCl}$ 
at $\mathrm{pH}$ 7.0), ${ }^{13)}$ Bacillus subtilis Marburg (Schaeffer's medium), ${ }^{14)}$ B. subtilis PCI $219(0.5 \%$ yeast extract, $0.3 \%$ Polypepton, $0.1 \%$ glucose and $0.1 \% \mathrm{NaCl}$ at pH 7.0), ${ }^{15)}$ Penicillum chrysogenum Thom Q-176 and Aspergillus oryzae IFO-4296 (Czapeck's medium at $\mathrm{pH} \quad 6.0)^{18\}}$ and Zygosaccharomyces soya ZS-5 and 7 Saccharomyces cerevisiae (YEPD medium containing $1 \%$ yeast extract, $4 \%$ Polypepton, $4 \%$ glucose at $\mathrm{pH}$ 5.8). ${ }^{13}$

Cells were grown to the $\log$ phase at $30^{\circ}$ or $37^{\circ} \mathrm{C}$ with shaking, harvested, washed with $0.067 \mathrm{M}$ phosphate buffer at $\mathrm{pH} 7.0$ for bacterial strains and at $\mathrm{pH}$ 6.0 for yeast and resuspended in the same buffer. Spores of $B$. subtilis were harvested from a 2-day-old culture grown at $37^{\circ} \mathrm{C}$, purified by the SDS-lysozyme treatment, ${ }^{14}$ and resuspended in distilled water. Fungal spores were collected from the 1-week-old culture on broth agar slant and the suspensions made in $0.067 \mathrm{M}$ phosphate buffer at $\mathrm{pH} 6.0$ were subjected to irradiation after filtration.

In order to investigate the effects of mutations affecting DNA repair on $\mathrm{NaCl}$ radiosensitization, the following derivatives of $E$. coli $\mathrm{K}-12$ were employed: P3478 (polAl), W3110( pol $^{+}$), AB2500 (uvrA6), AB2487 (recAl3), AB2480 (recA13 uvrA6), AB2499 (uvBs) and $\mathrm{AB} 2498$ (uvrC34) (kindly provided by Prof. H. S. Kaplan and Dr. J.C. Miller); AB1899 (lon $\left.{ }^{-}\right)$and AB1157 ( pol $^{+} \mathrm{rec}^{+}$) (by Dr. H. I. Adler); AB1886 (uvrA6) (by Prof. P. Haward-Flanders); AB2470
(recB2l), JC1553 (recAl) and $\mathrm{NH} 4033$ (recC22) (by Dr. M. Oishi). These strains were incubated in B2 broth at $37^{\circ} \mathrm{C}$ with shaking. If necessary, $5 \mu \mathrm{g} / \mathrm{ml}$ thymine was supplemented. Log-phase cells harvested by centrifugation were suspended in $0.067 \mathrm{M}$ phosphate buffer at $\mathrm{pH} 7.0$ to be subjected to irradiation.

Irradiation and determination of survivors. Cell suspensions were irradiated by ${ }^{60} \mathrm{Co}$ gamma rays with air bubbling. Dose rate was about $2.1 \mathrm{krad} / \mathrm{min}$ for most strains, $490 \mathrm{rad} / \mathrm{min}$ for radiosensitive mutants of E. coli and $4.9 \mathrm{krad} / \mathrm{min}$ for extremely radioresistant strains such as $M$. radiodurans. Cell concentrations of the suspensions were less than $5 \times 10^{8} \mathrm{cells} / \mathrm{ml}$. After irradiation cell survival was determined by counting the number of visible colonies developed on nutrient agar plates.

Reagents, Amino acids and chloramphenicol were kindly provided by Ajinomoto Co., Ltd. and Sankyo Co., Ltd., respectively. Actinomycin D was purchased from Sigma Chemical Co.

\section{RESULTS}

Effects of $1 \mathrm{M} \mathrm{NaCl}$ added during irradiation on radiosensitivities of different microorganisms The results of experiments to examine radio-

Table I. Radiosensitizing Effects of NaCl Added during IRRADIATION ON DIFFERENT MICROORGANISMS

\begin{tabular}{|c|c|c|c|c|}
\hline Strain & $\begin{array}{c}\text { Temp. of } \\
\text { incubation } \\
\left({ }^{\circ} \mathrm{C}\right)\end{array}$ & $\begin{array}{l}\mathrm{LD}_{10}{ }^{a} \\
\text { (krad) }\end{array}$ & $\begin{array}{l}\text { Radiosensi- } \\
\text { tizing effect of } \\
1 \mathrm{M} \mathrm{NaCl}{ }^{b}\end{array}$ & Source \\
\hline E. coli $\mathrm{B} / \mathrm{r}$ & 37 & 29.5 & H & T. Alper \\
\hline E. coli $\mathrm{B}$ & 37 & 10.3 & + & T. Alper \\
\hline E. coli $\mathrm{B}_{\mathrm{s}-1}$ & 37 & 4.2 & - & R. F. Hill \\
\hline E. coli $\mathrm{B}_{\mathrm{B}-2}$ & 37 & 4.4 & - & R. F. Hill \\
\hline E. coli $2-7$ (IAM1182) & 37 & 15.3 & H & IAM \\
\hline E. coli WP2 try ${ }^{-}$ & 37 & 12.6 & + & B. A. Bridges \\
\hline Pseudomonas fluorescens B3-1 & 30 & 5.7 & \pm & H. Ito \\
\hline Micrococcus radiodurans $\mathrm{R}_{I}$ & 30 & 965 & $H$ & A. W. Anderson \\
\hline Micrococcus radiophilus $\mathrm{RBD}$ & 30 & 665 & $H$ & N. F. Lewis \\
\hline Micrococcus sp. B12 & 30 & 960 & $H$ & This laboratory \\
\hline Streptococcus faecium R53 & 30 & 170 & H & C. F. Niven $\left(\mathbf{J}_{\mathbf{r}}\right)$ \\
\hline Tetracoccus soyae F-8 & 30 & 42 & + & S. Omata \\
\hline B. subtilis marburg 168 & 37 (vegetative cells) & 13.4 & + & This laboratory \\
\hline$n$ & (spores) & 184 & - & $n$ \\
\hline B. subtilis PCI 219 & 37 (spores) & 250 & - & IAM \\
\hline Penicillium chrysogenum Thom Q-176 & 30 (spores) & 40 & - & G. Nakamura \\
\hline Aspergillus oryzae IFO-4296 & 30 (spores) & 34 & - & G. Nakamura \\
\hline Zygosaccharomyces soya ZS-5 & 30 & 90 & $H$ & IAM \\
\hline Saccharomyces cerevisiae $\mathrm{H}-336$ & 30 & 300 & $H$ & IAM \\
\hline
\end{tabular}

a Determined in the absence of $\mathrm{NaCl}$.

$b+$, very effective; + , effective; - , ineffective.

c The authors acknowledge the kind supplies strains by the investigators listed in the Table. 

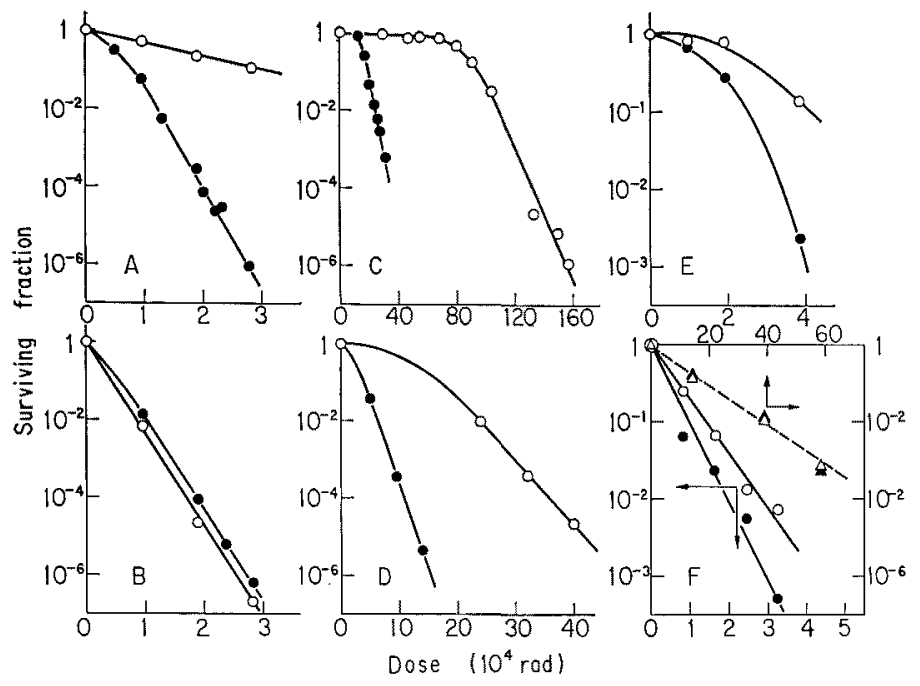

FIG. 1. Survival of Different Bacterial Cells Exposed to ${ }^{\circ} \mathrm{Co}$ Gamma Rays in the Presence (closed symbols) and Absence (open symbols) of $1 \mathrm{M} \mathrm{NaCl}$.

A, E. coli $\mathrm{B} / \mathrm{r} ; \mathrm{B}$, E. coli $\mathrm{B}_{\mathrm{s}-1} ; \mathrm{C}$, Micrococcus radiodurans $\mathrm{R}_{1} ; \mathrm{D}$, Streptococcus faecium $\mathrm{R} 53 ; \mathrm{E}$, Tetracoccus soyae F-8; F, Bacillus subtilis Marburg 168 (real line, vegetative cells; broken line, spores).

sensitizing effects of $1 \mathrm{M} \mathrm{NaCl}$ with different microorganisms are summarized in Table I. Some examples of survival curves in the presence and absence of $1 \mathrm{M} \mathrm{NaCl}$ are illustrated in Fig. 1. The radiosensitizing effect of $\mathrm{NaCl}$ was observed with the vegetative form, but not with bacterial and fungal spores. In a case of B. subtilis Marburg 168, log-phase cells were sensitive to the radiosensitizing effect of $\mathrm{NaCl}$, although not so remarkable perhaps because of the chain formation by this strain. Spores were insensitive to the effect of $\mathrm{NaCl}$ (Fig. 1F). of vegetative bacteria, remarkable radiosensitizing effect of $\mathrm{NaCl}$ was observed with the extremely radioresistant group such as $M$. radiodurans $\mathrm{R}_{1},{ }^{16)}$ Strep. faecium $\mathrm{R} 53,{ }^{10)} M$. radiophilus $\mathrm{RBD}^{11}$ and Micrococcus $\mathrm{sp} . \mathrm{B} 12,{ }^{12}$, where the characteristic shoulder of their survival curves was greatly diminished. Among E. coli strains, B/r and 2-7 (IAM1182) which are comparatively resistant to radiation increase their radiosensitivities in the presence of $1 \mathrm{M} \mathrm{NaCl}$. In contrast, radiosensitive strains $B_{5-1}$ and $B_{5-2}$ were not sensitized by the presence of $\mathrm{NaCl}$. With $M$. radiodurans, ${ }^{17,18)}$ Micrococcus sp. $\mathrm{B} 12^{12)}$ and $E$. coli $\mathrm{B} / \mathrm{r}^{19)}$ it was evidenced by the sedimentation analysis that these bacterial strains are endowed with the efficient DNA repair capacity. Thus, it is concluded that the effect of $\mathrm{NaCl}$ radiosensitization is confined to DNA-repair proficient strains in the vegetative form. It is also noted that a halophilic bacterium, Tetracoccus soyae $\mathrm{F}-8$, is sensitized by the presence of $1 \mathrm{M} \mathrm{NaCl}$ during irradiation (Fig. 1E).

Effect of mutations of genes governing the DNA repair on $\mathrm{NaCl}$ radiosensitization

As mentioned above, $\mathrm{NaCl}$ radiosensitization was observed with DNA-repair proficient strains. Subsequently, it would be expected that some DNA-repair-deficient mutants are insensitive to $\mathrm{NaCl}$ radiosensitization. Survival curves of pol, rec and $u v r$ mutants mostly derived from $E$. coli $\mathrm{K}-12$ and their progenitor strains were determined in the presence and absence of $1 \mathrm{M} \mathrm{NaCl}$. A lon ${ }^{-}$strain AB1899 was also tested. The results obtained are shown in Fig. 2. Progenitor strains AB1157 and W3110 were remarkably sensitized by the presence of $\mathrm{NaCl}$. Strains $\mathrm{AB} 2500$ ( uvr A6), AB1886 (uvrA6) (data not shown), AB2499 


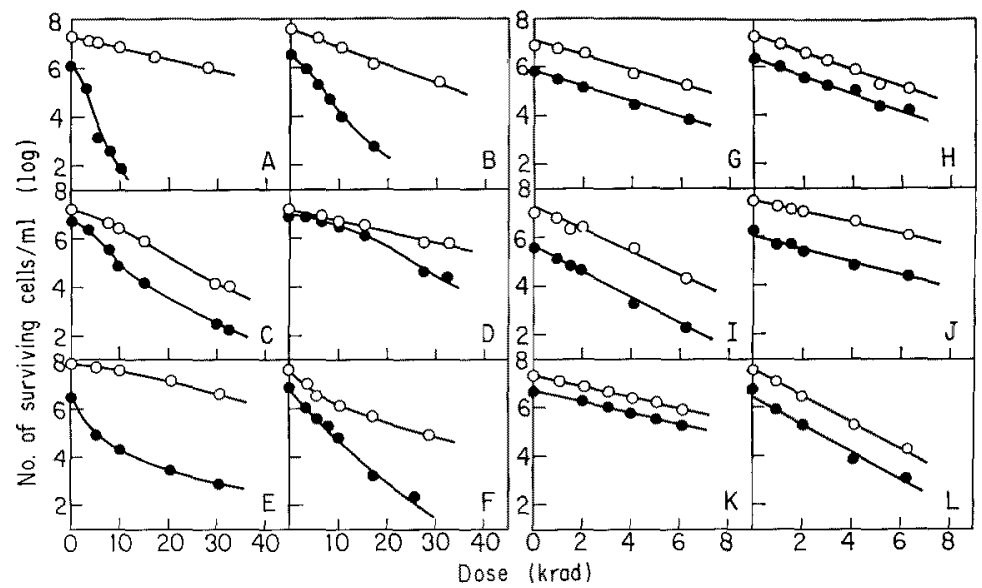

FIG. 2. Survival Curves of $E$. coli $\mathrm{K}-12$ Derivatives in the Presence (closed symbols) and Absence (open symbols) of $1 \mathrm{M} \mathrm{NaCl}$.

A, W3110 (pol+ $\left.\mathrm{rec}^{+} u v r^{+}\right) ; \mathrm{B}, \mathrm{AB} 1157\left(\mathrm{pol}^{+} \mathrm{rec}^{+} u v u^{+}\right) ; \mathrm{C}, \mathrm{AB} 2500(u v r A 6) ; \mathrm{D}, \mathrm{AB} 2499$ (uvrB5); E, AB2498 (uvrC34); F, AB1899 (lon ${ }^{-}$); G, P3478 (polAl); H, AB2487 (recA13); I, JC1553 (recAl); J, AB2470 (recB2l); K, NH4033 (recC22); L, AB2480 (recAl3 uvrA6).

(uwrB5) and AB2498 (uvrC34) as well as AB1899 (lon $\left.{ }^{-}\right)$were sensitized to some extent. In contrast, radiosensitivities of $\mathrm{P} 3478$ ( polA1), AB2487 (recA13), JC1553 (rec Al), AB2470 (recB21), NH4033 (recC22) and AB2480 (recA13 uvrA6) were not affected at all by the addition of $1 \mathrm{M} \mathrm{NaCl}$ during irradiation. These facts indicate that the mechanism for $\mathrm{NaCl}$ radiosensitization involves the inhibition of DNA-repair process controlled by pol and rec genes.

\section{Effects of solutes added during irradiation on \\ $\mathrm{NaCl}$ radiosensitization}

If the solute in test would react with $\mathrm{Cl}_{2}^{-}$ and/or $\mathrm{Cl}$ atoms which are assumed to be the attaching species, it would be expected to protect bacterial cells against the radiosensitizing action of $\mathrm{NaCl}$. Effects of various solutes on dose multiplying factors (DMF) of $1 \mathrm{M} \mathrm{NaCl}$ for $1 \%$ survival were determined with $E$. coli $\mathrm{B} / \mathrm{r}$. The results obtained are indicated in Table II. An example of survival curves determined with the effect of L-tryptophan is shown in Fig. 3.

Under the experimental condition of this study, the DMF value of $1 \mathrm{M} \mathrm{NaCl}$ in the absence of the solute varied from run to run
Table II. Effects of Solutes Added during IRRADIATION ON NaCl RADIOSENSITIZATION OF E. coli $\mathrm{B} / \mathrm{r}$

\begin{tabular}{|c|c|c|c|c|}
\hline \multirow[b]{2}{*}{ Solute } & \multirow{2}{*}{$\begin{array}{l}\text { Concen- } \\
\text { tration } \\
(\mathrm{M})\end{array}$} & \multicolumn{2}{|c|}{$\underset{\mathrm{NaCl}^{a}}{\mathrm{DMF}}$ of $1 \mathrm{M}$} & \multirow[b]{2}{*}{$\begin{array}{c}\text { Rela- } \\
\text { tive } \\
\text { DMF }^{b}\end{array}$} \\
\hline & & $\begin{array}{l}\text { in the } \\
\text { presence } \\
\text { of solute }\end{array}$ & $\begin{array}{l}\text { in the } \\
\text { absence } \\
\text { of solute }\end{array}$ & \\
\hline \multirow[t]{2}{*}{ Cystamine } & $6.7 \times 10^{-5}$ & 1.77 & 6.29 & 0.28 \\
\hline & $1 \times 10^{-2}$ & 1.39 & 6.29 & 0.22 \\
\hline \multicolumn{5}{|l|}{ 2-Mercapto- } \\
\hline \multirow[t]{2}{*}{ L-Tryptophan } & $6.7 \times 10^{-5}$ & 2.63 & 7.24 & 0.36 \\
\hline & $1 \times 10^{-3}$ & 1.73 & 7.24 & 0.24 \\
\hline \multirow[t]{2}{*}{ L-Histidine } & $6.7 \times 10^{-5}$ & 2.63 & 7.24 & 0.36 \\
\hline & $1 \times 10^{-3}$ & 1.65 & 7.24 & 0.23 \\
\hline \multirow[t]{2}{*}{ Glycine } & $6.7 \times 10^{-5}$ & 3.31 & 6.38 & 0.52 \\
\hline & $1 \times 10^{-4}$ & 2.72 & 6.38 & 0.43 \\
\hline \multicolumn{5}{|l|}{ Dimethyl- } \\
\hline amine & $1 \times 10^{-1}$ & 5.19 & 8.41 & 0.62 \\
\hline Ethanol & $6.7 \times 10^{-5}$ & 6.58 & 5.13 & 1.28 \\
\hline Formate & $6.7 \times 10^{-5}$ & 4.35 & 5.13 & 0.85 \\
\hline Nitrofurazone & $1 \times 10^{-4}$ & 1.21 & 8.41 & 1.44 \\
\hline
\end{tabular}

a Calculated for $1 \%$ survival $\left(=\frac{1 \% \text { Survival dose in the absence of } \mathrm{NaCl}}{1 \% \text { Survival dose in the presence of } 1 \mathrm{M} \mathrm{NaCl}}\right)$ o See text.

in a range of 5.13 to 8.41 . The effects of added solutes are represented in terms of the relative DMF defined as follows: 


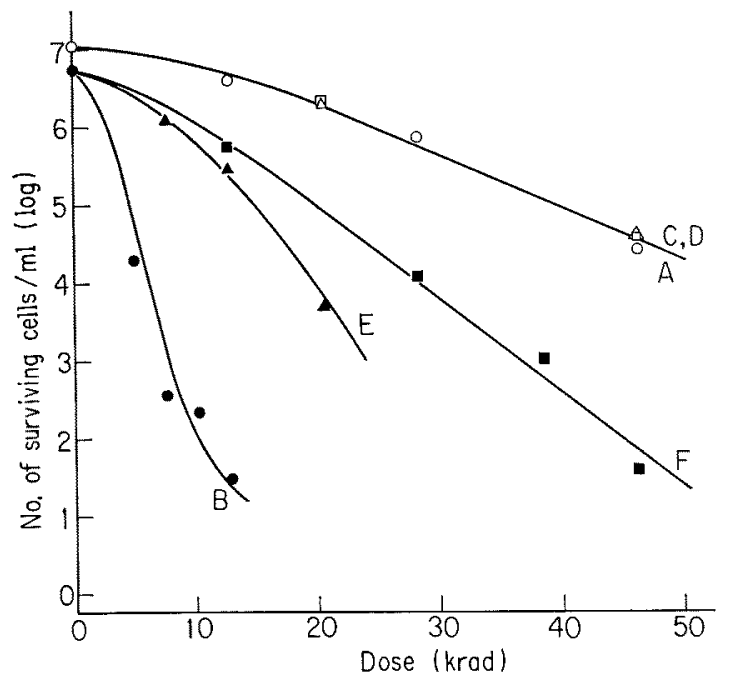

Fig. 3. Effect of L-Tryptophan Added during Irradiation on $\mathrm{NaCl}$ Radiosensitization $(E$. coli $\mathrm{B} / \mathrm{r}$ log-phase cells).

A, Control; B, $1 \mathrm{M} \mathrm{NaCl} ; \mathrm{C}, 6.7 \times 10^{-6} \mathrm{M}$ L-tryptophan; D, $1 \times 10^{-3} \mathrm{M}$ L-tryptophan; E, $1 \mathrm{M} \mathrm{NaCl}+$ $6.7 \times 10^{-5} \mathrm{M}$ L-tryptophan; F, $1 \mathrm{M} \mathrm{NaCl}+1 \times 10^{-3} \mathrm{M}$ L-tryptophan.

\section{Relative DMF}

DMF of $\mathrm{NaCl}$ in the presence of the solute $=\mathrm{DMF}$ of $\mathrm{NaCl}$ in the absence of the solute
The more effective solute for the removal of $\mathrm{NaCl}$ radiosensitization gives the smaller value of relative DMF. As can be seen in Table II, thiol compounds and amino acids such as tryptophan and histidine which react with $\mathrm{Cl}_{2}^{-}$radical anions remove the radiosensitizing effect of $\mathrm{NaCl}$. However, glycine which was found not to react with $\mathrm{Cl}_{2}^{-}$anions $^{20)}$ was also effective for the removal of $\mathrm{NaCl}$ radiosensitization, although it was a little less effective than tryptophan and histidine. Dimethylamine, a charge scavenger, was not so effective. Hydrogen-donating substances such as ethanol and formate and an electron-affinic radiosensitizer nitrofurazone exhibited almost no effect on the enhancement of radiosensitizing effect of $\mathrm{NaCl}$.

\section{Dependence of radiosensitizing effect of $\mathrm{NaCl}$ upon its concentrations}

If $\mathrm{NaCl}$ radiosensitization were due to the action of $\mathrm{Cl}_{2}^{-}$anion radicals and/or $\mathrm{Cl}$ atoms, their formation would require the chloride concentrations sufficient for the spur reaction. $^{3,21 \text { ) }}$ Subsequently, the relationship between extracellular chloride concentration dur-

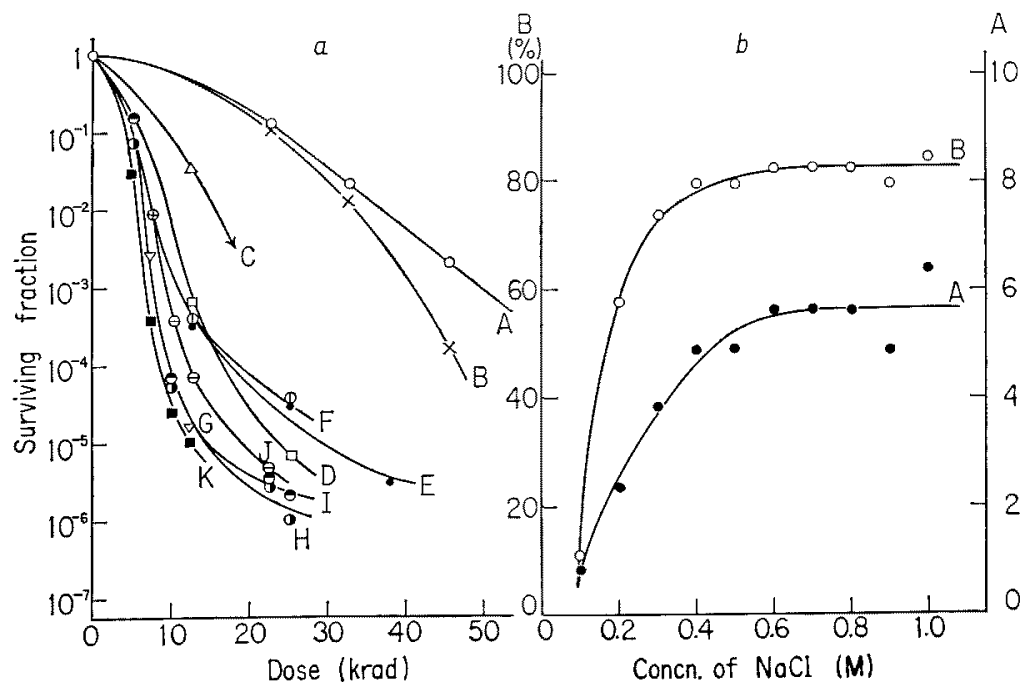

FIG. 4. Effects of Concentration of $\mathrm{NaCl}$ on Its Radiosensitizing Action (E. coli $\mathbf{B} / \mathrm{r}$ log-phase cells).

$a$, Survival curves at different $\mathrm{NaCl}$ concentrations (A, control; B, $0.1 \mathrm{M} ; \mathrm{C}, 0.2 \mathrm{M} ; \mathrm{D}, 0.3 \mathrm{M} ; \mathrm{E}$, $0.4 \mathrm{M} ; \mathrm{F}, 0.5 \mathrm{M} ; \mathrm{G}, 0.6 \mathrm{M} ; \mathrm{H}, 0.7 \mathrm{M} ; \mathrm{I}, 0.8 \mathrm{M} ; \mathrm{J}, 0.9 \mathrm{M} ; \mathrm{K}, 1.0 \mathrm{M})$.

$b$, Relationship between $\mathrm{NaCl}$ concentration and the extent of radiosensitizing effect (A, represented by DMF; B, by \% inhibition, see text). 
ing irradiation and the extent of its radiosensitizing effect was determined with $E$. coli $\mathrm{B} / \mathrm{r}$ and the result is shown in Fig. 4. Two curves represented by different parameters similarly show that $\mathrm{NaCl}$ is effective for radiosensitization at concentrations of $0.1 \mathrm{M}$ or higher and the chloride concentration-radiosensitizing effect curve reaches the plateau at about $0.6 \mathrm{M}$.

Effects of inhibitors of RNA and protein syntheses added during postirradiation incubation on $\mathrm{NaCl}$ radiosensitization

The inhibition of RNA and protein synthesis during postirradiation incubation was found to reduce the survival of DNA-repair-proficient strains of $E$. coli and $M$. radiodurans by blocking the repair of radiation-produced DNAstrand breaks. ${ }^{22,23)}$ In connection with this finding, effects of actinomycin D and chloramphenicol added during postirradiation incubation on survival of $E$. coli $\mathrm{B} / \mathrm{r} \log$-phase cells were determined to examine the correlation between $\mathrm{NaCl}$ radiosensitization and the inhibition of RNA and protein syntheses.
In Fig. 5, curves $\mathrm{F}$ and $\mathrm{H}$ represent the doseeffect relation being found when cells are irradiated in $1 \mathrm{M} \mathrm{NaCl}$-containing phosphate buffer, harvested by centrifugation and then reincubated for $2 \mathrm{hr}$ in $\mathrm{B} 2$ broth containing either actinomycin D or chloramphenicol, respectively, at the constant concentration. The toxic effects of these two metabolic inhibitors to decrease cell survival were almost independent of radiation dose, i.e., they exhibited the "additive" effect. If they interfere with the same process required for the cell viability as that damaged by radiosensitizing action of $\mathrm{NaCl}$, the additional decrease in cell survival by the addition of these metabolic inhibitors sould not be so significant as compared with that by the presence of only $\mathrm{NaCl}$ during irradiation. Then, with increasing doses, curves $\mathrm{F}$ (irradiated with $\mathrm{NaCl}$ and reincubated with actinomycin $\mathrm{D}$ ) and $\mathrm{H}$ (irradiated with $\mathrm{NaCl}$ and reincubated with chloramphenicol) in Fig. 5 should become closer to curve $\mathrm{D}$ which is the survival curve for cells irradiated with $\mathrm{NaCl}$ and reincubated without any inhibitor. However, it was not

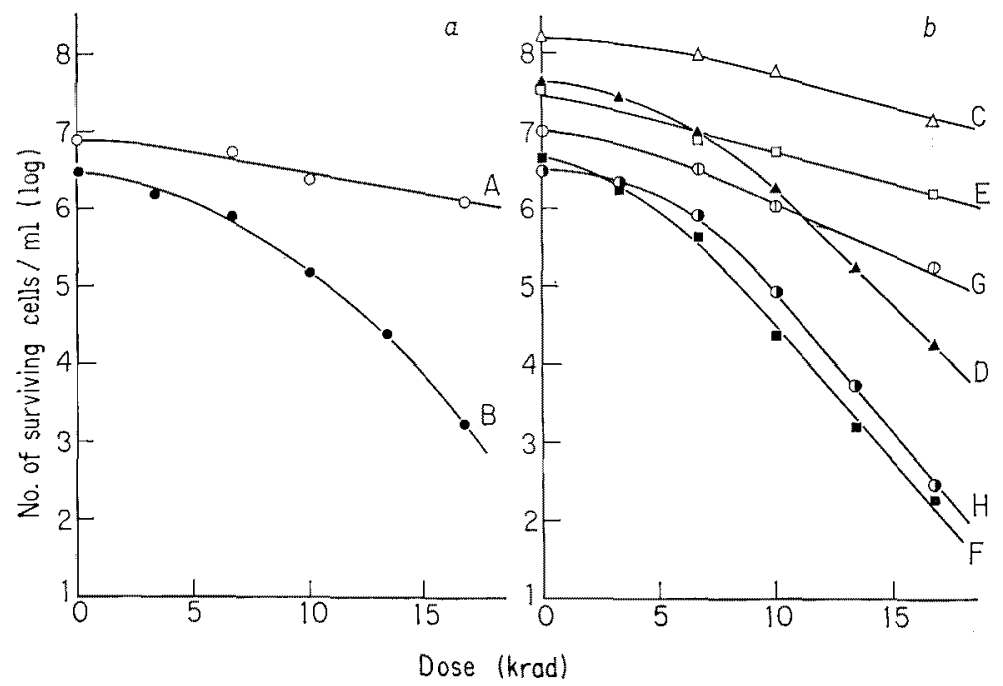

FIG. 5. Effects of RNA and Protein Syntheses Inhibitors Added during Post-irradiation Incubation on $\mathrm{NaCl}$ Radiosensitization of $E$. coli $\mathrm{B} / \mathrm{r}$.

A, C, E and G; irradiated in NaCl-free phosphate buffer.

$B, D, F$ and $\mathrm{H}$; irradiated in $1 \mathrm{M} \mathrm{NaCl}$ containing phosphate buffer.

a: immediately after irradiation.

$b$ : after 2-hr postirradiation incubation in $\mathrm{B} 2$ broth at $37^{\circ} \mathrm{C}(\mathrm{C} \& \mathrm{D}$, no additive; $\mathrm{E} \& \mathrm{~F}, 34 \mu \mathrm{g} / \mathrm{ml}$ actinomycin $\mathrm{D} ; \mathrm{G} \& \mathrm{H}, 18 \mu \mathrm{g} / \mathrm{ml}$ chloramphenicol.) 
the case as shown in Fig. 5.

\section{DISCUSSION}

In this study, the radiosensitizing effect of $\mathrm{NaCl}$ was observed with the radioresistant vagetative forms, but not with radiosensitive strains. The former group of radioresistant strains has been found to be endowed with the efficient DNA-repair capacity. With DNArepair-proficient $E$. coli strains W3110, AB1157 as well as $B / r$, the remarkable radiosensitizing effect of $\mathrm{NaCl}$ was determined. In contrast, mutations in certain genes controlling the DNA repair process in $E$. coli clearly affected the effectiveness of $\mathrm{NaCl}$ during irradiation. As seen in Fig. 3, the pol and rec mutations completely remove the effect of $\mathrm{NaCl}$. In addition, it must be noted that the above DNA-repair-proficient strains were similarly sensitized to radiation by the presence of $1 \mathrm{M}$ $\mathrm{NaCl}$ near to the level of sensitive mutants P3478 ( $\left.\mathrm{pol}^{-}\right)$and AB2487 ( $\mathrm{rec}^{-}$) (Fig. 3). These results indicate that $\mathrm{NaCl}$ radiosensitization is closely related with the DNA repair inhibition and that in the case of $E$. coli it results from the inhibition of pol- and recdependent repair of DNA.

The addition of some solute during irradiation was also found to abolish the radiosensitizing effect of $\mathrm{NaCl}$. The additives highly or considerably reactive with $\mathrm{Cl}_{2}^{-}$radical anions such as thiol compounds, tryptophan and histidine were very effective to abolish the radiosensitizing effect of $\mathrm{NaCl}^{4,20)}$ This supports a view that an attacking species in $\mathrm{NaCl}$ radiosensitization is $\mathrm{Cl}_{2}^{-}$radical anions. However, glycine was also found to protect $E$. coli $\mathrm{B} / \mathrm{r}$ cells to some extent against the radiosensitizing action of $\mathrm{NaCl}$, although it was much less reactive with $\mathrm{Cl}_{2}^{-}$anions. In this case, added glycin might be effective not as a competitors, but through other mode of action-probably as a protector for some vital component against the damaging action of $\mathrm{Cl}_{2}^{-}$anions. Futher investigations are still required to establish a view on the attacking species in $\mathrm{NaCl}$ radiosensitization. The reac- tion process to form $\mathrm{Cl}_{2}^{--}$radical anions has been postulated as follows: $:^{2,4}$

$$
\begin{aligned}
& \mathrm{H}_{2} \mathrm{O} \rightarrow \mathrm{M} \rightarrow \mathrm{H}_{2} \mathrm{O}^{+}+\mathrm{e}^{-} \\
& \mathrm{H}_{2} \mathrm{O}^{+}+\mathrm{H}_{2} \mathrm{O} \rightarrow \mathrm{H}_{3} \mathrm{O}^{+}+\mathrm{OH} \\
& \mathrm{Cl}^{-}+\mathrm{H}_{3} \mathrm{O}^{+}+\mathrm{OH} \rightarrow \mathrm{Cl}+2 \mathrm{H}_{2} \mathrm{O} \\
& \mathrm{Cl}^{-}+\mathrm{Cl} \rightarrow \mathrm{Cl}_{2}^{-}
\end{aligned}
$$

In neutral solution, reaction (3) may take place in a spur. Thus, if the attacking species in $\mathrm{NaCl}$ radiosensitization were $\mathrm{Cl}$ atoms or $\mathrm{Cl}_{2}^{-}$anions, spur reaction (3) should occur even at the minimum intracellular chloride concentration effective for $\mathrm{NaCl}$ radiosensitization.* The minimum extracellular chloride concentration was determined to be about $0.1 \mathrm{M}$, as shown in Fig. 2. The intracellular chloride concentration in this case is estimated to be $\sim 0.03 \mathrm{M}$ in average, based on an experiment using ${ }^{38} \mathrm{Cl}-\mathrm{NaCl}$ (unpublished data). Scince the halflife value of reaction (3) is estimated to be $\sim 10^{-8} \mathrm{sec}$ for $0.03 \mathrm{M}$ of the chloride concentration as $\mathrm{K}_{\mathrm{OH}+\mathrm{Cl} 1}=4 \times 10^{9}$ $\mathrm{M}^{-1} \mathrm{Sec}^{-1}$ in $0.8 \mathrm{~N} \mathrm{H}_{2} \mathrm{SO}_{4}{ }^{24)}$ the $\mathrm{Cl}_{2}^{-}$formation by spur reactions is possible at this intracellular chloride concentration. If there were heterogenous chloride distribution in bacterial cells, the possibility of occuring reaction (3) would increase. These considerations support a view that the attacking species may be $\mathrm{Cl}_{2}^{-}$ radical anions and/or $\mathrm{Cl}$ atoms.

The effect of actinomycin D and chloramphenicol added after irradiation in the presence of $\mathrm{NaCl}$ may give us another information on the action mechanism of radiosensitizing $\mathrm{NaCl}$. Some reports ${ }^{22,23,26,27)}$ described the involvement of certain RNA and protein synthesis in the DNA repair process in $E$. coli as well as in $M$. radiodurans. The results obtained in this study indicate that effects of actinomycin D and chloramphenicol, which are the inhibitor of DNA-dependent RNA synthesis and protein synthesis, respectively, were "additive" for the radiosensitizing action of $\mathrm{NaCl}$ over the radiation dose range studied, that is, independent of doses of irradiation in

* It has been described that $\mathrm{NaCl}$ radiosensitization is due to the short-lived species formed from $\mathrm{Cl}^{-}$ ions, but not from $\mathrm{Na}^{+}$ions. ${ }^{25)}$ 
the presence of $\mathrm{NaCl}$. This fact suggests that the inhibition of RNA and protein syntheses due to these metabolic inhibitors may not be involved in the primary process of $\mathrm{NaCl}$ radiosensitization. Some other mechanism might be operative in the inhibition of DNA repair by irradiation in the presence of $\mathrm{NaCl}$. Further investigation on cellular damage due to $\mathrm{NaCl}$ added during irradiation are required for the elucidation of the basic mechanism for $\mathrm{NaCl}$ radiosensitization.

Acknowledgements. The authors wish to express their thanks to Dr. M. Imamura for his advice and to Miss F. Kaneko for her excellent technical assistance. They are also grateful to Ajinomoto Co., Ltd. and Sankyo Co., Ltd. for supplying reagents. This study was supported by research grants from Ministry of Education and Kaken Chemical Co., Ltd.

\section{REFERENCES}

1) A. Matsuyama, Y. Okazawa, M. Namiki and $Y$. Sumiki, J. Radiat. Res., 1-2, 98 (1960).

2) A. Matsuyama, M. Namiki and Y. Okazawa, Radiat. Res, 30, 687 (1967).

3) A. Matsuyama and M. Namiki, Agric. Biol. Chem., 29, 593 (1965).

4) Su-Jen Shih Chen, S. Arai and A. Matsuyama, Sci. Pap. Inst. Phys. Chem. Res., 68, 21 (1974).

5) M. Simic, E. L. Powers, M. Centilli and M. Cross, Int. J. Radiat. Biol., 25, 43 (1974).

6) J. L. Redpath and D. L. Dewey, ibid., 25, 189 (1974).

7) J. L. Redpath, ibid., 27, 493 (1975).

8) F. L. Haas and C. O. Doudney, Proc. Natl. Acad. Sci. U.S.A., 43, 871 (1957).
9) Y. Okazawa and A. Matsuyama, Agric. Biol. Chem., 31, 1505 (1967).

10) A. Matsuyama, M. J. Thornley and M. Ingram, J. Appl. Bacteriol., 27, 110 (1964).

11) N. F. Lewis, J. Gen. Microbiol., 66, 29 (1971).

12) A. Matsuyama, Y. Okazawa, H. Arai and M. Mifune, Sci. Pap. Inst. Phys. Chem. Res., 67, 35 (1973).

13) T. Ueno, M. Kawai and S. Omata, J. Ferment, Technol., 39, 383 (1961).

14) F. Yatagai, T. Takahashi, Y. Kitajima and A. Matsuyama, J. Radiat. Res., 15, 90 (1974).

15) A. Matsuyama, Y. Okazasa and M. Namiki, Agric. Biol. Chem., 25, 367 (1961).

16) A. W. Anderson, H. C. Nordan, F. R. Cain, G. Parrish and D. Duggan, Food Technol., 10, 575 (1956).

17) S. Kitayama and A. Matsuyama, Biochem. Biophys. Res. Commun., 33, 418 (1968).

18) A. D. Burrell, P. Feldschreiber and C. J. Dean, Biochim. Biophys. Acta, 247, 38 (1971).

19) R. A. McGrath and R. W. Williams, Nature, 212, 534 (1966).

20) G. E. Adams, J. E. Aldrick, R. H. Bisby, R. B. Cundall, J. L. Redpath and R. L. Willson, Radiat. Res., 49, 278 (1972).

21) M. Anbar and J. K. Thomas, J. Phys. Chem., 68, 3829 (1964).

22) S. Kitayama and A. Matsuyama, Agric. Biol. Chem., 35, 644 (1971).

23) A. K. Ganesan and K.C. Smith, J. Bacteriol., 111, 575 (1972).

24) M. Burton and K. C. Kurien, J. Phys. Chem., 63, 899 (1959).

25) M. Namiki, Y. Okazawa and A. Matsuyama, Agric. Biol. Chem, 25, 108 (1961).

26) W. Wehrli and M. Stachelin, Bacteriol. Rev., 35, 290 (1971).

27) C. K. K. Nair and D. S. Pradhan, Int. J. Radiat. Biol., 28, 385 (1975). 